\title{
ANALISA BUDAYA ORGANISASI DAN KEPUASAN KERJA PEGAWAI TERHADAP KINERJA PEGAWAI AGEN ASURANSI JIWA DI BUMIPUTERA KANTOR WILAYAH SYARIAH JAKARTA
}

\author{
Ruslan \\ Universitas Mercubuana, Jakarta Barat \\ ruslan@bhinnekalife.com
}

\begin{tabular}{l}
\hline Keyword \\
\hline $\begin{array}{l}\text { Organizational Culture, Job } \\
\text { Satisfaction, employee performance }\end{array}$
\end{tabular}

Abstract

Satisfaction, employee performance

The purpose of this study was to find out and explain scientifically the influence of organizational culture and job satisfaction on the performance of employees of the Bumiputera life insurance agent in the Jakarta Syariah Regional Office.

This study uses a quantitative descriptive approach, namely a research approach carried out by processing and presenting data using the basis of a statistical numerical approach in the form of more concise information. This information can be represented by the mean, median, frequency, percentage and various diagrams. The data analysis method used in this study is the Multiple Linear Regression model. Based on the results of the study All independent variables positively influence the measured dependent variable. Based on the correlation matrix analysis between dimensions on organizational culture variables and employee agent employee performance, the strongest influence on the integrity dimension of the organizational culture variable on the independence dimension of the employee agent agent's performance variable. While the correlation matrix analysis between dimensions on the variable job satisfaction and employee agent insurance performance, the strongest influence on the dimensions of coworkers from the variable job satisfaction on the dimensions of the effectiveness of the variable employee performance insurance agent.

(C)2019 JMB, All right reserved

\section{PENDAHULUAN}

\section{Latar Belakang Masalah}

Bumiputera merupakan sebuah perusahaan asuransi jiwa milik pribumi yang berbentuk usaha bersama (mutual). Produk asuransi jiwa yang dipasarkannya terbagi dalam dua kelompok lini bisnis (divisi) yaitu : Asuransi Jiwa Konvensional dan Asuransi Jiwa Syariah. Produk asuransi jiwa konvensional merupakan produk pertama yang dipasarkan sejak awal berdirinya Bumiputera. Ada 4 (empat) jenis produk konvensional yang dipasarkan saat ini, yaitu : Mitra Ekawarsa, Mitra Deposito, Mitra Eksekutif, dan Mitra Perlindungan Kecelakaan Diri. Sedangkan produk asuransi jiwa syariah mulai dipasarkan sejak tahun 2003 seiring perkembangan kebutuhan masyarakat Indonesia akan asuransi jiwa syariah. Asuransi jiwa syariah adalah jenis asuransi jiwa yang seluruh kegiatan transaksinya berbasiskan ajaran dan ketentuan yang diatur dalam agama Islam (syariah). Terdapat 5 (lima) jenis produk dalam asuransi jiwa syariah ini, yaitu : Mitra Mabrur, Mitra Sakinah, Mitra Iqra, Mitra Iqra Plus, dan Mitra Mabrur Plus. Saat ini yang masih dipasarkan adalah Mitra Iqra Plus dan Mitra Mabrur Plus.

Salah satu unsur terpenting dalam memasarkan dan menjual produk-produk tersebut diatas adalah pegawai agen asuransi jiwa. Ada 2 jenis tugas pokok pegawai agen asuransi jiwa, yaitu tugas produksi dan tugas penagihan. Tugas produksi adalah mencari, mendata, memprospek dan menjual polis kepada sebanyak-banyaknya calon pemegang polis sehingga membeli produk asuransi jiwa dan 
menjadi pemegang polis Bumiputera. Tugas penagihan adalah melakukan penagihan premi asuransi jiwa kepada pemegang polis yang memilih pembayaran premi asuransi jiwanya melalui pegawai agen asuransi jiwa. Berdasarkan tugas pokok pegawai agen asuransi jiwa tersebut, kinerja pegawai agen asuransi jiwa dapat diukur berdasarkan berapa banyak polis yang berhasil dijualnya (produksi polis) dan berapa banyak premi yang berhasil ditagihnya (produksi premi).

Penulis melakukan survei pendahuluan melalui wawancara dengan enam orang pegawai dan mengobservasi hal-hal yang dilihat dan dirasakan penulis saat berada di lokasi objek penelitian. Dari survei tersebut penulis menemukan beberapa fenomena yang terjadi di lokasi objek penelitian.

Dalam hal budaya organisasi, pada tahun 2006 melalui SK Direksi No. 5/DIR/2006 Bumiputera telah mengeluarkan dan mensosialisasikan Surat Keputusan tentang penerapan budaya organisasi kepada seluruh unit kerja. Penjabaran budaya organisasi tertuang dalam akronim BUMIPUTERA, sebagai berikut : "B" = Berorientasi pada kepuasan pelanggan, "U" = Utamakan proses kerja yang benar, "M" = Menjadi teladan dan panutan, "I" = Ikut menjaga tradisi kebersamaan dilandasi rasa memiliki perusahaan, "P" = Profitabilitas menjadi sasaran, "U" = Ulet dalam melakukan pekerjaan, "T" = Taat terhadap Tuhan Yang Maha Esa dan peraturan perusahaan, "E" = Efektif dan efisien dalam segala kegiatan, " $R$ " $=$ Ramah dan tulus ikhlas terhadap rekan kerja, "A" = Amanah dalam mengemban tugas perusahaan.

Dari hasil wawancara terungkap bahwa pada tahun 2006 kegiatan sosialisasi mengenai budaya organisasi secara proaktif sering dilakukan. Akan tetapi di tahun-tahun berikutnya kegiatan tersebut sudah tidak dilakukan. Sehingga pada saat sekarang terindikasi banyak pegawai yang belum sepenuhnya memahami dan menerapkan budaya organisasi dalam keseharian pekerjaannya. Sebagai contoh mengenai budaya berorientasi pada kepuasan pelanggan, dimana pada penerbitan polis pelanggan terkadang lewat dari tanggal yang diharapkan. Terjadi kesalahan pada polis akibat salah dalam pemasukan data polis. Penagihan premi yang datang terlambat sehingga terjadi premi tertunda. Pengurusan klaim yang terkadang terlalu lama. Contoh lain mengenai budaya amanah dalam mengemban tugas perusahaan, dimana pegawai agen asuransi jiwa terkadang tidak langsung menyerahkan premi yang telah dibayarkan pemegang polis kepada perusahaan. Mengenai budaya taat terhadap Tuhan Yang Maha Esa, dimana pegawai agen asuransi jiwa terkadang tidak menjalankan kewajibannya sebagai hamba Tuhan seperti sholat jumat bagi pegawai muslim. Dalam hal kepuasan kerja, pada tahun 2007
Bumiputera melakukan kebijakan restrukturisasi kantor wilayah pemasaran dan penggunaan sistem aplikasi komputer yang cukup ketat. Dengan adanya restrukturisasi kantor wilayah pemasaran tersebut seorang pegawai agen asuransi jiwa hanya boleh memasarkan produk asuransi jiwa di wilayahnya saja. Dimana sebelumnya seorang pegawai agen asuransi jiwa dapat melakukan pemasaran di wilayah mana saja yang dapat dijangkau olehnya. Sehingga dengan demikian ruang lingkup pemasarannya menjadi lebih terbatas. Agar tetap mencapai produktifitas polis dan premi yang tinggi setiap kantor wilayah melakukan rekrutmen pegawai agen asuransi secara proaktif sehingga terjadi penambahan jumlah pegawai yang cukup signifikan. Dari tabel diatas memang terlihat terjadi peningkatan jumlah produksi polis dan premi. Akan tetapi jika dilihat dari rata-rata produksi per pegawai terjadi penurunan. Penggunaan aplikasi komputer yang cukup ketat mengakibatkan tertundanya proses penerbitan polis dikarenakan harus melalui kelengkapan pengisian dan validitas data. Selain itu pula tenaga pengentrian data yang terbatas dimana satu permintaan polis dapat diproses dalam waktu lima hingga sepuluh menit. Koneksi jaringan data ke kantor pusat terkadang terganggu pula. Hal inilah yang menjadi salah satu indikator ketidakpuasan kerja pegawai karena terhambatnya pelayanan kepada pelanggan.

Kemudian pada tahun 2009 ada peraturan baru tentang besarnya komisi dan provisi untuk agen asuransi jiwa yang lebih rendah dari peraturan sebelumnya. Pada peraturan sebelumnya komisi dan provisi untuk agen asuransi jiwa sebesar 3\% dari nilai premi dan polis yang dihasilkan, tetapi dengan adanya kebijakan baru tersebut komisi dan provisi menjadi hanya $2 \%$ dari nilai premi dan polis yang dihasilkan. Hal inilah yang membuat banyak pegawai agen asuransi jiwa mengeluh karena secara langsung mengakibatkan kesejahteraan ekonomi pegawai agen asuransi jiwa semakin menurun.

Selain itu pula dari sisi produk asuransi jiwa yang dipasarkan kurang kompetitif di pasaran. Dimana produk dari asuransi jiwa dari perusahaan asuransi jiwa lainnya sudah berbasis unit link dimana produk asuransinya sudah dikaitkan dengan produk investasi, sedangkan produk dari Bumiputera masih memakai produk tradisional asuransi jiwa murni. Hal ini juga yang menjadi salah satu ketidakpuasan kerja pegawai agen asuransi jiwa Bumiputera.

Berdasarkan fakta dan fenomena tersebut diatas penulis tertarik untuk meneliti lebih jauh dan menjelaskan secara ilmiah mengenai pengaruh budaya organisasi dan kepuasan kerja pegawai terhadap kinerja pegawai agen asuransi jiwa di Bumiputera Kantor Wilayah Syariah Jakarta. Hal itulah yang menjadikan latar 
belakang dilakukan penulisan ini

\section{Rumusan Masalah}

Dalam penulisan ini penulis fokus pada dua variabel yang mempengaruhi kinerja pegawai yaitu budaya organisasi dan kepuasan kerja. Sehingga berdasarkan latar belakang dan identifikasi masalah yang telah diuraikan diatas, maka dapat dirumuskan masalah penulisan sebagai berikut :

a. Apakah budaya organisasi berpengaruh terhadap kinerja pegawai agen asuransi jiwa Bumiputera Kantor Wilayah Syariah Jakarta?

b. Apakah kepuasan kerja berpengaruh terhadap kinerja pegawai agen asuransi jiwa Bumiputera Kantor Wilayah Syariah Jakarta?

c. Apakah budaya organisasi dan kepuasan kerja secara bersama-sama berpengaruh terhadap kinerja pegawai agen asuransi jiwa Bumiputera Kantor Wilayah Syariah Jakarta

\section{Tujuan Penulisan}

Maksud penulisan ini adalah untuk mengetahui dan menjelaskan secara ilmiah pengaruh budaya organisasi dan kepuasan kerja terhadap kinerja pegawai agen asuransi jiwa Bumiputera Kantor Wilayah Syariah Jakarta. Sesuai dengan maksud penulisan tersebut, maka tujuan penulisan ini adalah :

a. Untuk mengetahui dan menjelaskan kuat pengaruh budaya organisasi terhadap kinerja pegawai agen asuransi jiwa Bumiputera Kantor Wilayah Syariah Jakarta.

b. Untuk mengetahui dan menjelaskan kuat pengaruh kepuasan kerja terhadap kinerja pegawai agen asuransi jiwa Bumiputera Kantor Wilayah Syariah Jakarta.

c. Untuk mengetahui dan menjelaskan kuat pengaruh budaya organisasi dan kepuasan kerja secara bersama-sama terhadap kinerja pegawai agen asuransi jiwa Bumiputera Kantor Wilayah Syariah Jakarta.

\section{TINJAUAN PUSTAKA}

\section{Budaya Organisasi}

Beberapa definisi budaya organisasi dikemukakan oleh para ahli. Budaya organisasi merupakan salah satu subsistem dalam organisasi mengenai kepercayaan dan nilainilai yang dianut bersama di dalam organisasi dan merupakan pedoman bagi perilaku para anggotanya (Schermerhorn, 1996).

Davis (1989) menyatakan bahwa budaya organisasi merupakan pola keyakinan dan nilainilai (values) organisasi yang dipahami, dijiwai dan dipraktekkan oleh organisasi sehingga pola tersebut memberikan arti tersendiri dan menjadi dasar aturan berperilaku dalam organisasi.

Menurut Udaya (1994) menyatakan bahwa budaya organisasi sebagai nilai-nilai dominan yang disebarluaskan dalam organisasi yang dijadikan filosofi kerja pegawai yang menjadi panduan bagi kebijakan organisasi dalam mengelola pegawai dan konsumen.

Sedangkan menurut Moeljono (2005) mendefinisikan bahwa budaya organisasi adalah perekat organisasi yang mengikat anggota organisasi melalui nilai-nilai yang ditaati, peralatan simbolik, dan cita-cita sosial yang ingin dicapai.

Stoner (1996) mendefinisikan budaya organisasi sebagai suatu cognitive framework yang meliputi sikap, nilai-nilai, norma perilaku dan harapan-harapan yang disumbangkan oleh anggota organisasi.

\section{Kepuasan Kerja}

Kepuasan kerja adalah sikap emosional yang menyenangkan dan mencintai pekerjaannya. Sikap ini dicerminkan oleh moral kerja, kedisiplinan, dan prestasi kerja. Kepuasan kerja dinikmati dalam pekerjaan, luar pekerjaan dan kombinasi dalam dan luar pekerjaan (Hasibuan, 1999).

As'ad (2003) menjelaskan bahwa variabel yang dapat dijadikan indikasi menurunnya kepuasan kerja adalah tingginya tingkat absensi (absenteeism), tingginya keluar masuknya pegawai (turnover), menurunnya produktivitas kerja atau prestasi kerja pegawai (performance).

Selain itu menurut Martoyo (2000) definisi atau pengertian kepuasan kerja adalah keadaan emosional pegawai di mana terjadi ataupun tidak terjadi titik temu antara nilai balas jasa kerja pegawai dari perusahaan/organisasi dengan tingkat nilai balas jasa yang memang diinginkan oleh pegawai yang bersangkutan. Balas jasa kerja pegawai ini, baik yang berupa finansial maupun yang nonfinansial. Bila kepuasan kerja terjadi, maka pada umumnya tercermin pada perasaan pegawai terhadap pekerjaannya, yang sering diwujudkan dalam sikap positif pegawai terhadap pekerjaannya dan segala sesuatu yang dihadapi ataupun ditugaskan kepadanya di lingkungan kerjanya. Kepuasan atau ketidakpuasan pegawai tergantung pada perbedaan antara apa yang diharapkan. Sebaliknya, apabila yang didapat pegawai lebih rendah daripada yang diharapkan akan menyebabkan pegawai tidak puas.

\section{Kinerja Pegawai}

Beberapa ahli lain mempunyai pendapat bahwa kinerja adalah hasil kerja secara kualitas dan kuantitas yang dicapai oleh seorang pegawai dalam melaksanakan tugasnya sesuai dengan tanggung jawab yang diberikan kepadanya (Mangkunegara, 2000). 
Kinerja atau unjuk kerja adalah pencapaian atau prestasi seseorang berkenaan dengan tugas-tugas yang dibebankan kepadanya (Marwansyah, 2010).

Hasibuan (1999) menjelaskan kinerja mempunyai hubungan yang erat dengan masalah produktivitas, karena merupakan indikator dalam menentukan bagaimana usaha untuk mencapai tingkat produktivitas yang tinggi dalam suatu organisasi. Kinerja merupakan fungsi interaksi antara kemampuan atau ability (A), motivasi atau motivation (M), dan kesempatan atau opportunity $(\mathrm{O})$, jadi kinerja $=f(\mathrm{~A} \times \mathrm{M} \times \mathrm{O})$. Artinya kinerja merupakan fungsi dari kemampuan, motivasi, dan kesempatan (Robbins, 2001).

Menurut Gomez (1995) definisi kinerja pegawai adalah ungkapan seperti output, efisiensi, serta efektivitas sering dihubungkan dengan produktivitas. Bernardin (1993) mengatakan bahwa kinerja pegawai tergantung pada kemampuan, usaha kerja dan kesempatan kerja yang dapat dinilai dari output dalam jangka waktu tertentu.

Pendapat lain disampaikan oleh Mathis (2002) ada tiga faktor utama yang dapat mempengaruhi bagaimana individu/seorang pegawai dalam bekerja, yaitu : kemampuan individual untuk melakukan pekerjaan tersebut, tingkat usaha yang dicurahkan, dan dukungan organisasi. Kinerja individual ditingkatkan sampai tingkat dimana ketiga komponen tersebut ada dalam diri pegawai. Akan tetapi, kinerja berkurang apabila salah satu faktor ini dikurangi atau tidak ada.

Beberapa pengertian kinerja dalam Rivai (2010) dapat dikemukakan sebagai berikut : Kinerja merupakan pelaksanaan fungsi-fungsi yang dituntut. Kinerja adalah perbuatan, prestasi, dan pameran umum keterampilan (Whitmore, 1997); Kinerja merupakan kombinasi dari kemampuan, usaha, dan kesempatan yang dapat dinilai dari hasil kerja (Sulistiyani, 2003); Kinerja sebagai kualitas dan kuantitas dari pencapaian tugas-tugas baik yang dilakukan oleh individu, kelompok, maupun perusahaan (Osborn, 1991).

\section{METODOLOGI PENELITIAN}

\section{Metode Penelitian}

Penelitian ini menggunakan pendekatan deskriptif kuantitatif yaitu suatu pendekatan penelitian yang dilakukan dengan cara pengolahan dan penyajian data menggunakan dasar pendekatan angka statistik dalam bentuk informasi yang lebih ringkas. Informasi tersebut bisa diwakili oleh mean, median, frekuensi, persentase dan berbagai diagram.

\section{Populasi dan Sampel}

Dalam penelitian ini mengambil populasi dengan karakteristik / kriteria yaitu pegawai agen asuransi jiwa yang berstatus aktif, pendidikan minimal SLTA, dan mempunyai produksi dalam periode Juni 2012 sampai dengan Desember 2012. Dari kriteria tersebut, didapat populasi berukuran 109 orang pegawai. Menurut Hair (1995) untuk memperoleh hasil analisis yang signifikan dan lebih akurat disarankan ukuran sampel minimal berkisar 100 - 200 responden dengan tingkat kesalahan 5\%. Dalam penelitian ini seluruh populasi yang berjumlah 109 orang dijadikan sebagai anggota sample (responden) sehingga sesuai dengan saran Hair diatas. Metode pengambilan data (sampling) yang digunakan adalah metode sensus melalui survei dengan angket (kuesioner).

\section{Tekhnik Analisis Data}

Metode analisis data yang digunakan dalam penelitian ini adalah model Regresi Linear Berganda. Analisa Regresi diigunakan untuk menentukan tingkat pengaruh suatu variabel terhadap variabel lainnya. Tehnik analisanya adalah bagaimana kausalitas atau hubungan pengaruh budaya organisasi (X1) dan kepuasan kerja (X2) terhadap kinerja pegawai (Y).

Formula model regresi linear berganda sebagai berikut :

$$
\mathrm{Y}=\mathrm{a}+\mathrm{b} 1 . \mathrm{X} 1+\mathrm{b} 2 . \mathrm{X} 2
$$

Dimana :

$$
\begin{array}{ll}
\mathrm{Y} & =\text { Kinerja Pegawai } \\
\mathrm{a} & =\text { Konstanta (variabel tetap) } \\
\mathrm{b} 1, \mathrm{~b} 2 & =\text { Koefisien Regresi } \\
\mathrm{X} 1 & =\text { Budaya Organisasi } \\
\mathrm{X} 2 & =\text { Kepuasan Kerja }
\end{array}
$$

Untuk menguji model diatas menggunakan uji asumsi klasik yang merupakan metode kuantitatif yaitu pengolahan data dengan menggunakan rumus yang dalam penelitian ini dioperasikan melalui program SPSS 18.0. Uji asumsi klasik yang digunakan dalam penelitian ini sebagai berikut :

a) Uji Normalitas

Digunakan untuk menguji apakah dalam model regresi, variabel bebas dan variabel terikat mempunyai distribusi normal atau setidaknya mendekati normal. Pada prinsipnya normalitas dapat disimpulkan dengan melihat penyebaran data (titik) padasumbu diagonal dari grafik atau dengan melihat histogram dari residualnya. Dalam penelitian ini uji normalitas menggunakan rumus Kolmogorov Smirnov untuk mengetahui apakah data penelitian berdistribusi normal atau tidak. Jika nilai 
probabilitas (sig) lebih besar dari taraf signifikansi 0,05 maka data terdistribusi normal. Selain itu dapat dilihat juga dari gambar grafik yang dihasilkan Histogram.

b) Uji Linearitas

Digunakan untuk menguji apakah kedua variabel memiliki hubungan yang bersifat linear atau tidak. Dalam penelitian ini uji linearitas menggunakan tabel ANOVA. Jika nilai probabilitas (sig) lebih besar dari taraf signifikansi 0,05 maka data bersifat linier.

c) Uji Multikolinearitas

Uji multikolinearitas dilakukan untuk mengetahui hubungan yang sempurna antar variabel independen dalam model regresi. Gejala multikolinieritas dapat dilihat dari nilai tolerance dan nilai Varian Inflation Factor (VIF). Bila nilai VIF lebih kecil dari 10 dan nilai toleransinya di atas 0,1 atau $10 \%$ maka dapat disimpulkan bahwa model regresi tersebut tidak terjadi multikolinieritas.

d) Uji Heteroskedastisitas

Uji heteroskedastisitas dilakukan untuk menguji apakah dalam sebuah model regresi terjadi ketidaksamaan varian dari residual, dari satu pengamatan ke pengamatan lain. Jika varian dari residual dari satu pengamatan ke pengamatan lain tetap, maka disebut homoskedastisitas dan jika varian berbeda disebut heteroskedastisitas. Model regresi yang baik adalah model yang tidak terjadi heteroskedastisitas. Untuk mendeteksi adanya heteroskedastisitas dapat digunakan grafik Scatterplot yang dihasilkan dari output program SPSS 18 , apabila gambar menunjukkan bahwa titik-titik menyebar secara acak dan tersebar baik di atas maupun di bawah angka 0 pada sumbu $\mathrm{Y}$, hal ini dapat disimpulkan tidak terjadinya heteroskedastisitas pada model regresi.

Sedangkan untuk menguji hipotesis dan korelasi digunakan alat uji sebagai berikut :

a) Uji t

Digunakan untuk menguji apakah hipotesis dapat diterima atau tidak dengan membandingkan $t_{\text {hitung dengan }}$ $t_{\text {tabel}}$. Jika $t_{\text {hitung }}>t_{\text {tabel }}$ dan nilai probabilitas (sig) lebih kecil dari taraf signifikansi $(0,05)$ maka hipotesis dapat diterima.

b) Uji F

Digunakan untuk menguji signifikansi model (persamaan) regresi dengan membandingkan nilai $F_{\text {hitung }}$ dengan $F_{\text {tabel }}$. Jika $F_{\text {hitung }}>F_{\text {tabel }}$ dan nilai probabilitas (sig) lebih kecil dari taraf signifikansi $(0,05)$ maka model dapat dikatakan layak untuk memprediksi hubungan variabel. c) Analisa Koefisien Korelasi

Digunakan untuk mengetahui ada tidaknya hubungan antar variabel, bagaimana arah hubungannya dan seberapa besar hubungan tersebut.

\section{HASIL PENELITIAN DAN PEMBAHASAN}

\section{Budaya Kerja}

Berdasarkan hasil pengukuran variabel budaya organisasi mendapatkan nilai sebesar 4,55. Hasil ini dapat diinterpretasikan bahwa nilai-nilai dari budaya organisasi dipahami dan diterapkan oleh pegawai agen asuransi jiwa. Dengan menerapkan nilai-nilai budaya organisasi pegawai agen asuransi bisa menghasilkan kinerja yang lebih baik. Dari 4 dimensi yang diukur, dimensi integritas mendapatkan nikai tertinggi yaitu 4,65. Untuk lebih lengkapnya hasil tersebut dijelaskan dalam analisis tiap dimensi sebagai berikut :

a. Dimensi Integritas.

Berdasarkan hasil pengukuran didapatkan nilai dimensi integritas adalah 4,65. Hasil ini dapat diinterpretasikan bahwa pegawai agen asuransi memahami dan menerapkan nilai-nilai integritas. Dengan integritas pegawai agen asuransi akan mempunyai pedoman dalam bekerja baik secara agama maupun masyarakat yang pada akhirnya menghasilkan kinerja yang lebih baik. Dibandingkan dengan nilai dari dimensi lainnya, nilai dari dimensi integritas merupakan nilai tertinggi. Hasil ini dapat diartikan bahwa dimensi integritas memberikan kontribusi pengaruh terbesar terhadap variabel budaya organisasi.

b. Dimensi Percaya Rekan Kerja

Berdasarkan hasil pengukuran, didapatkan nilai dimensi percaya rekan kerja adalah 4,60. Hasil ini dapat diinterpretasikan bahwa pegawai agen asuransi dapat bersikap ramah dan menghargai pendapat rekan kerjanya. Dengan hal tersebut maka akan terbentuk budaya organisasi yang erat dalam hal kerjasama antar pegawai.

c. Dimensi Profesional

Berdasarkan hasil pengukuran, didapatkan nilai dimensi profesional adalah 4,51. Hasil ini dapat diinterpretasikan bahwa pegawai agen asuransi memahami nilai-nilai profesionalisme dalam melakukan pekerjaannya sebagai pegawai agen asuransi.

\section{d. Dimensi Peduli}

Berdasarkan hasil pengukuran tabel didapatkan nilai dimensi peduli adalah 4,45. 
Hasil ini dapat diinterpretasikan bahwa pegawai agen asuransi memahami nilainilai kepedulian terhadap perusahaan.

\section{Kepuasan Kerja}

Berdasarkan hasil pengukuran variabel kepuasan kerja mendapatkan nilai sebesar 3,93. Hasil ini dapat diinterpretasikan bahwa kepuasan kerja pegawai agen asuransi sudah cukup baik. Dari 5 dimensi yang diukur, dimensi pekerjaan itu sendiri mendapatkan nilai tertinggi yaitu 4,19 . Untuk lebih lengkapnya hasil tersebut dijelaskan dalam analisis tiap dimensi sebagai berikut :

a. Dimensi Penghasilan.

Berdasarkan hasil pengukuran tabel didapatkan nilai dimensi penghasilan adalah 3,30. Hasil ini dapat diinterpretasikan bahwa pegawai agen asuransi antara merasa puas dan merasa tidak puas dengan penghasilan yang diterima walaupun lebih cenderung sedikit kepada merasa puas.

b. Dimensi Promosi.

Berdasarkan hasil pengukuran tabel, didapatkan nilai dimensi promosi adalah 3,98. Hasil ini dapat diinterpretasikan bahwa pegawai agen asuransi merasa puas dengan promosi karir yang diberikan perusahaan.

c. Dimensi Rekan Kerja.

Berdasarkan hasil pengukuran tabel, didapatkan nilai dimensi rekan kerja adalah 4,05. Hasil ini dapat diinterpretasikan bahwa pegawai agen asuransi merasa puas dengan sikap rekan kerja dalam membantu dan mendukung pekerjaannya. .

d. Dimensi Atasan.

Berdasarkan hasil pengukuran tabel $5.5 \mathrm{di}$ atas, didapatkan nilai dimensi rekan kerja adalah 4,12. Hasil ini dapat diinterpretasikan bahwa pegawai agen asuransi merasa puas dengan sikap atasannya dalam menangani bawahan.

e. Dimensi Pekerjaan Itu Sendiri.

Berdasarkan hasil pengukuran tabel, didapatkan nilai dimensi rekan kerja adalah 4,19. Hasil ini dapat diinterpretasikan bahwa pegawai agen asuransi merasa puas dengan pekerjaan itu sendiri. Dibandingkan dengan nilai dari dimensi lainnya, nilai dari dimensi pekerjaan itu sendiri merupakan nilai tertinggi. Hasil ini dapat diartikan bahwa dimensi pekerjaan itu sendiri memberikan kontribusi pengaruh terbesar terhadap variabel kepuasan kerja.

\section{Analisis Deskripsi Variabel Kinerja Pegawai}

Berdasarkan hasil pengukuran tabel variabel kinerja mendapatkan nilai sebesar 3,96. Hasil ini dapat diinterpretasikan bahwa kinerja pegawai agen asuransi cukup baik. Dari 5 dimensi yang diukur, dimensi komitmen kerja mendapatkan nilai tertinggi yaitu 4,67. Untuk lebih lengkapnya hasil tersebut dijelaskan dalam analisis tiap dimensi sebagai berikut :

a. Dimensi Kuantitas.

Berdasarkan hasil pengukuran tabel 5.6 di atas, didapatkan nilai dimensi kuantitas adalah 3,42. Hasil ini dapat diinterpretasikan bahwa kinerja pegawai agen asuransi dari sisi kuantitas rata-rata cukup baik. Namun masih perlu ditingkatkan untuk menjadi lebih baik lagi.

b. Dimensi Kualitas.

Berdasarkan hasil pengukuran didapatkan nilai dimensi kualitas adalah 3,72. Hasil ini dapat diinterpretasikan bahwa kinerja pegawai agen asuransi dari sisi kualitas rata-rata cukup baik. Namun masih perlu ditingkatkan untuk menjadi lebih baik lagi.

c. Dimensi Ketepatan Waktu.

Berdasarkan hasil pengukuran tabel, didapatkan nilai dimensi ketepatan waktu adalah 4,63. Hasil ini dapat diinterpretasikan bahwa kinerja pegawai agen asuransi dari sisi ketepatan waktu ratarata sudah baik.

d. Dimensi Efektifitas.

Berdasarkan hasil pengukuran tabel didapatkan nilai dimensi efektifitas adalah 3,21 . Hasil ini dapat diinterpretasikan bahwa kinerja pegawai agen asuransi dari sisi efektifitas rata-rata cukup baik

e. Dimensi Kemandirian.

Berdasarkan hasil pengukuran di atas, didapatkan nilai dimensi kemandirian adalah 4,11. Hasil ini dapat diinterpretasikan bahwa kinerja pegawai agen asuransi dari sisi kemandirian rata-rata sudah baik.

f. Dimensi Komitmen Kerja.

Berdasarkan hasil pengukuran didapatkan nilai dimensi komitmen kerja adalah 4,67. Hasil ini dapat diinterpretasikan bahwa kinerja pegawai agen asuransi dari sisi komitmen kerja ratarata sudah baik.

\section{Uji Normalitas}

Uji normalitas menggunakan rumus Kolmogorov Smirnov untuk mengetahui apakah data penelitian berdistribusi normal atau tidak.

Tabel 4.1

Hasil Uji Normalitas Variabel Kinerja, Budaya Organisasi, dan Kepuasan Kerja

\begin{tabular}{|l|r|r|r|}
\hline \multirow{2}{*}{} & \multicolumn{3}{|c|}{ Kolmogorow-Smirnov $^{{ }^{2}}$} \\
\cline { 2 - 4 } & Statistic & \multicolumn{1}{c|}{ df } & \multicolumn{1}{c|}{ Sig. } \\
\hline Kinerja &, 079 & 109 &, 092 \\
Eudaya Organisasi &, 083 & 109 &, 063 \\
Kepuasan Kerja &, 085 & 109 &, 053 \\
\hline
\end{tabular}

a. Lilliefors Significance Correction 
Sumber : Output SPSS 18.

Tabel di atas menunjukkan bahwa nilai probabilitas (sig.) variabel kinerja sebesar 0,092, budaya organisasi sebesar 0,063, dan kepuasan kerja sebesar 0,053. Karena nilai sig. ketiga variabel diatas lebih besar dari taraf signifikan $(\alpha)$ 0,05 maka data ketiga variabel berdistribusi normal.

Selain itu dilakukan uji normalitas melalui Histogram dan Normal P-P Plot, seperti yang terlihat pada gambar di bawah ini :

Gambar 4.2

Histogram Uji Normalitas

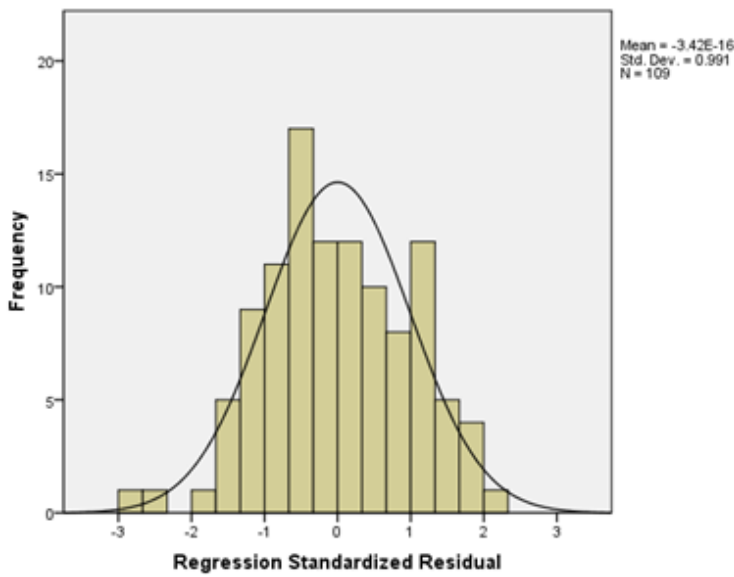

Dari gambar 4.2 diatas terbentuk sebuah gambar kurva yang menyerupai lonceng. Sehingga memenuhi persyaratan dari uji normalitas adalah bila kurva terbentuk seperti lonceng maka hal ini dapat diasumsikan bahwa data penelitian sudah terdistribusi secara normal.

Gambar 4.3

Normal P-P Plot Uji Normalitas

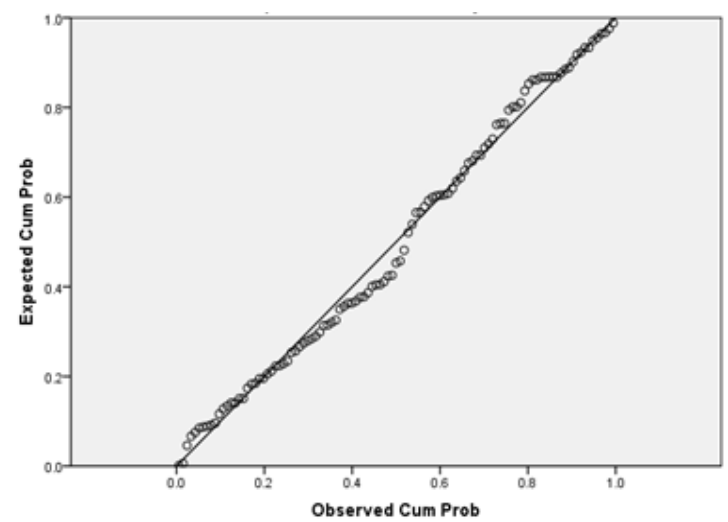

Dari gambar 4.3 diatas didapatkan hasil bahwa semua data terdistribusi secara normal, sebaran data berada disekitar garis diagonal. Sehingga memenuhi persyaratan dari uji normalitas adalah jika data menyebar di sekitar garis diagonal dan mengikuti arah garis diagonal, maka model regresi memenuhi asumsi normalitas.

\section{Pembahasan}

Berdasarkan hasil pengujian secara statistik dapat dilihat dengan jelas bahwa pengaruh yang diberikan variabel independen budaya organisasi bersifat positif artinya semakin tingginya budaya organisasi maka akan mengakibatkan semakin tinggi pula kinerja pegawai agen asuransi yang dihasilkan. Hasil tersebut sesuai dengan hipotesis pertama yang diajukan. Pengaruh positif diberikan juga oleh variabel independen kepuasan kerja artinya semakin tingginya kepuasan kerja maka akan mengakibatkan semakin tinggi pula kinerja pegawai agen asuransi yang dihasilkan. Hasil ini sesuai dengan hipotesis kedua yang diajukan. Kedua variabel independen tersebut berpengaruh secara bersama-sama (simultan) terhadap variabel dependen. Hasil tersebut sesuai dengan hipotesis ketiga yang diajukan, bahwa budaya organisasi dan kepuasan kerja berpengaruh secara bersamasama (simultan) terhadap kinerja pegawai agen asuransi. Hasil penelitian ini juga sesuai dengan hasil penelitian sebelumnya ( Budiarti, 2008 ). Penjelasan pengaruh variabel tersebut dijelaskan sebagai berikut:

\section{Pengaruh Budaya Organisasi terhadap Kinerja Pegawai Agen Asuransi}

Hasil pengujian hipotesis pertama (H1) telah membuktikan terdapat pengaruh antara budaya organisasi terhadap kinerja pegawai agen asuransi. Melalui hasil perhitungan nilai $t_{\text {hitung }}$ sebesar 4,479 dengan taraf signifikansi 0,000 dan $\mathrm{SC}_{(\beta)}=0,387$. Dimana taraf signifikansi tersebut lebih kecil dari 0,05 dan memiliki nilai $t_{\text {hitung }}>$ $t_{\text {tabel }}$ sebesar 1,660. Berdasarkan tabel 4.4 nilai $\mathrm{SC}_{(\beta)}$ sebesar 0,387 menunjukkan tingkat hubungan yang moderat. Sehingga pengujian ini secara statistik membuktikan bahwa budaya organisasi berpengaruh positif signifikan moderat terhadap kinerja pegawai agen asuransi. Artinya ada pengaruh signifikan budaya organisasi terhadap kinerja pegawai agen asuransi di Bumiputera.

Melihat pengaruh korelasi antar dimensi dari variabel budaya organisasi dengan dimensi dari variabel kinerja pegawai agen asuransi menunjukkan bahwa nilai $\mathrm{r}$ tertinggi ( 0,518 ) terdapat pada pengaruh dimensi integritas dari variabel budaya organisasi terhadap dimensi kemandirian dari variabel kinerja pegawai agen asuransi. Pengaruh tersebut menunjukkan bahwa setiap pegawai agen asuransi di Bumiputera yang memiliki dimensi integritas lebih tinggi dalam budaya organisasinya akan mempengaruhi secara signifikan terhadap dimensi kemandirian dalam kinerja pegawai agen asuransi tersebut atau sebaliknya jika dimensi kemandirian para pegawai agen asuransi ingin ditingkatkan, maka upaya untuk meningkatkan dimensi integritas para pegawai agen asuransi juga harus 
ditingkatkan.

Jika memperhatikan nilai dari profil dimensi integritas 4.65 ( dari skala 5 ) menunjukkan nilai yang tinggi dan nilai profil dimensi kemandirian 4.11 juga menunjukkan nilai tinggi. Nilai tersebut menguatkan hasil penelitian ini bahwa dimensi integritas dari pegawai agen asuransi berkorelasi positif dan signifikan terhadap dimensi kemandirian.

Hasil analisis antar dimensi dari variabel budaya organisasi terhadap variabel kinerja pegawai agen asuransi menunjukkan hanya dimensi integritas saja yang memiliki pengaruh positif signifikan terhadap keseluruhan dimensi dari variabel kinerja pegawai agen asuransi. Sedangkan dimensi lainnya dari variabel budaya organisasi ( dimensi percaya rekan kerja, profesionalisme, dan peduli ) memiliki pengaruh yang signifikan hanya pada sebagian dimensi dari variabel kinerja pegawai. Hal ini dapat diinterpretasikan bahwa dimensi integritas dari variabel budaya organisasi sangat berpengaruh dan berperan penting terhadap keseluruhan dimensi dari kinerja pegawai agen asuransi. Dimana dalam penelitian ini, indikator dari dimensi integritas yang digunakan adalah ketaatan kepada Tuhan, ketaatan kepada peraturan, dan dapat menjaga amanah. Semakin ketiga indikator tersebut meningkat maka akan meningkat pula keseluruhan dimensi dari kinerja pegawai agen asuransi. Begitu juga sebaliknya jika terjadi penurunan terhadap ketiga indikator tersebut maka menurun pula keseluruhan dimensi dari kinerja pegawai agen asuransi. Hal tersebut tidak terlihat pada dimensi percaya rekan kerja, profesionalisme, dan peduli. Jika terjadi perubahan pada dimensi tersebut maka pengaruh signifikan hanya terjadi pada sebagian dimensi saja dari kinerja pegawai. Oleh karena itu jika ingin meningkatkan kinerja pegawai melalui budaya organisasi hal yang pertama yang diperhatikan adalah peningkatan integritas pegawai agen asuransi.

\section{Pengaruh Kepuasan Kerja terhadap Kinerja Pegawai Agen Asuransi}

Hasil pengujian hipotesis kedua (H2) telah membuktikan terdapat pengaruh antara kepuasan kerja terhadap kinerja pegawai agen asuransi. Melalui hasil perhitungan nilai $t_{\text {hitung }}$ sebesar 4,170 dengan taraf signifikansi 0,000 dan $\mathrm{SC}_{(\beta)}=$ 0,361 . Dimana taraf signifikansi tersebut lebih kecil dari 0,05 dan memiliki nilai $t_{\text {hitung }}>t_{\text {tabel }}$ sebesar 1,660. Berdasarkan tabel 4.4 nilai $\mathrm{SC}_{(\beta)}$ sebesar 0,361 menunjukkan tingkat hubungan yang moderat. Sehingga pengujian ini secara statistik membuktikan bahwa kepuasan kerja berpengaruh positif signifikan moderat terhadap kinerja pegawai agen asuransi. Artinya ada pengaruh signifikan kepuasan kerja terhadap kinerja pegawai agen asuransi di Bumiputera.

Melihat pengaruh korelasi antar dimensi dari variabel kepuasan kerja dengan dimensi dari variabel kinerja pegawai agen asuransi menunjukkan bahwa nilai $\mathrm{r}$ tertinggi ( 0,431$)$ terdapat pada pengaruh dimensi rekan kerja dari variabel kepuasan kerja terhadap dimensi efektifitas dari variabel kinerja pegawai agen asuransi. Pengaruh tersebut menunjukkan bahwa setiap pegawai agen asuransi di Bumiputera yang memiliki dimensi kepuasan terhadap rekan kerja lebih tinggi dalam budaya organisasinya akan mempengaruhi secara signifikan terhadap dimensi efektifitas dalam kinerja pegawai agen asuransi tersebut atau sebaliknya jika dimensi efektifitas para pegawai agen asuransi ingin ditingkatkan, maka upaya untuk meningkatkan dimensi kepuasan terhadap rekan kerja para pegawai agen asuransi juga harus ditingkatkan.

Namun jika memperhatikan tabel 5.5 nilai dari profil dimensi rekan kerja 4,05 (dari skala 5 ) menunjukkan nilai yang tinggi dan dari tabel 5.6 nilai profil dimensi efektifitas 3,21 yang menunjukkan nilai sedang. Nilai tersebut menunjukkan hasil penelitian ini bahwa untuk dimensi kepuasan terhadap rekan kerja dari pegawai agen asuransi berkorelasi positif dan signifikan terhadap dimensi efektifitas dengan catatan korelasi dimensi tersebut membutuhkan penelitian yang lebih mendalam lagi.

Hasil analisis antar dimensi dari variabel kepuasan kerja terhadap variabel kinerja pegawai agen asuransi menunjukkan hanya dimensi pekerjaan itu sendiri saja yang memiliki pengaruh positif signifikan terhadap keseluruhan dimensi dari variabel kinerja pegawai agen asuransi. Sedangkan dimensi lainnya dari variabel kepuasan kerja ( dimensi penghasilan, promosi, rekan kerja, dan atasan ) memiliki pengaruh yang signifikan hanya pada sebagian dimensi dari variabel kinerja pegawai. Hal ini dapat diinterpretasikan bahwa dimensi pekerjaan itu sendiri dari variabel budaya organisasi sangat berpengaruh dan berperan penting terhadap keseluruhan dimensi dari kinerja pegawai agen asuransi. Jika kepuasan pegawai agen asuransi terhadap pekerjaan itu sendiri meningkat maka keseluruhan dimensi dari kinerja pegawai akan meningkat pula. Oleh karena itu jika ingin meningkatkan kinerja pegawai melalui kepuasan kerja, hal yang pertama yang diperhatikan adalah peningkatan kepuasan terhadap pekerjaan itu sendiri. Hal tersebut dapat dilakukan melalui pemberian pemahaman mengenai pekerjaan sebagai agen asuransi dan seluk beluknya sehingga menimbulkan minat dan kecintaan terhadap pekerjaan tersebut.

\section{Pengaruh Simultan Budaya Organisasi dan Kepuasan Kerja terhadap Kinerja Pegawai Agen Asuransi}

Dari hasil pengujian hipotesis ketiga (H3) menggunakan koefisien korelasi ganda (R), koefisien determinasi ( $R$ Square), uji $t$, dan uji $F$ yang terangkum dalam tabel 5.16 dan persamaan regresi (R.3) membuktikan bahwa budaya 
organisasi dan kepuasan kerja secara simultan berpengaruh secara signifikan moderat terhadap kinerja pegawai agen asuransi. Hal ini dapat dibuktikan dengan nilai $\mathrm{R}=0,653$ yang masuk dalam kriteria moderat berdasarkan tabel 4.4. Nilai R Square $=0,427$ yang menunjukkan bahwa sebesar $42,7 \%$ secara simultan budaya organisasi dan kepuasan kerja berpengaruh terhadap kinerja pegawai agen asuransi sedangkan $57,3 \%$ sisanya dipengaruhi faktor lain diluar model persamaan regresi (R.3). Dari model persamaaan regresi tersebut dapat diinterpretasikan bahwa :

a. Jika variabel budaya organisasi meningkat dengan asumsi variabel kepuasan kerja tetap, maka kinerja pegawai juga akan meningkat.

b. Jika variabel kepuasan kerja meningkat dengan asumsi variabel budaya organisasi tetap, maka kinerja pegawai juga akan meningkat.

c. Variabel budaya organisasi mempunyai kontribusi pengaruh yang lebih besar dibandingkan variabel kepuasan kerja terhadap kinerja pegawai agen asuransi.

Dalam penelitian ini, model persamaan regresi tersebut menghasilkan nilai konstanta minus $(-17,478)$. Seandainya dalam penelitian ini menghasilkan nilai tertinggi pada seluruh variabel bebas yang digunakan ( budaya organisasi dan kepuasan kerja ), dalam hal ini nilai 5 (skala likert tertinggi yang digunakan) maka akan tetap menghasilkan nilai variabel kinerja pegawai yang minus $(-9,218)$. Hasil ini dapat diinterpretasikan bahwa diperlukan pengaruh dari variabel lain yang sangat besar (banyak) sehingga pengaruh yang diberikan akan menghasilkan nilai positif bagi variabel kinerja pegawai. Hal tersebut dapat dipahami karena pekerjaan sebagai pegawai agen asuransi merupakan sebuah profesi yang sangat khusus yang membutuhkan kemampuan khusus pula. Untuk dapat memiliki kemampuan tersebut diperlukan pengaruh baik dari dalam maupun dari luar diri pegawai agen asuransi itu sendiri.

Oleh karena itu peneliti memprediksikan bahwa masih diperlukan penambahan pengaruh dari variabel bebas lainnya sehingga membuat variabel kinerja pegawai menjadi positif. Semoga di kesempatan lain penelitian ini dapat dikembangkan dengan menambahkan variabel bebas lainnya ke dalam penelitian ini seperti motivasi, pelatihan, kompensasi, kepemimpinan, dan lain sebagainya.

\section{KESIMPULAN DAN SARAN}

\section{Kesimpulan}

Penelitian ini mengenai pengaruh budaya organisasi dan kepuasan kerja terhadap kinerja pegawai agen asuransi jiwa di Bumiputera Kantor Wilayah Syariah Jakarta. Berdasarkan data primer yang diperoleh dari penyebaran koesioner maka dilakukan pengujian reliabilitas untuk mengetahui jawaban responden konsisten dari waktu ke waktu dan dilakukan pengujian validitas untuk mengukur sah tidaknya suatu koesioner. Hasil dari uji reliabilitas dan validitas menunjukkan bahwa seluruh pernyataan dalam setiap variabel dinyatakan reliabel dan valid.

Dalam uji asumsi klasik yang meliputi uji normalitas, linearitas, multikolinieritas, dan heteroskedastisitas menunjukkan bahwa data berdistribusi normal, bersifat linear, tidak ditemukan adanya korelasi antara variabel independen dan tidak terjadi heteroskedastisitas.

Berdasarkan hasil penelitian dan pembahasan yang telah diuraikan, maka dapat di tarik kesimpulan sebagai berikut:

1. Profil dari budaya organisasi, kepuasan kerja dan kinerja pegawai agen asuransi di Bumiputera Kantor Wilayah Syariah Jakarta menunjukkan hasil yang cukup baik. Semua variabel independen berpengaruh secara positif terhadap variabel dependen yang diukur.

2. Budaya organisasi berpengaruh positif signifikan moderat terhadap kinerja pegawai agen asuransi sebesar 33,3\%. Hal ini menunjukkan bahwa semakin tinggi budaya organisasi yang diterapkan maka semakin tinggi pula kinerja pegawai agen asuransi. Namun adanya pengaruh yang moderat antara budaya organisasi terhadap kinerja pegawai dapat disimpulkan bahwa ada faktor-faktor lain yang dapat dijadikan prediksi untuk meningkatkan kinerja pegawai agen asuransi.

3. Kepuasan kerja berpengaruh positif signifikan moderat terhadap variabel kinerja pegawai agen asuransi sebesar 31,8\%. Hal ini menunjukkan bahwa semakin tinggi kepuasan kerja maka semakin tinggi pula kinerja pegawai agen asuransi. Namun adanya pengaruh yang moderat antara kepuasan kerja terhadap kinerja pegawai dapat disimpulkan bahwa ada faktor-faktor lain yang dapat dijadikan prediksi untuk meningkatkan kinerja pegawai agen asuransi.

4. Budaya organisasi dan kepuasan kerja secara simultan berpengaruh positif dan signifikan moderat terhadap kinerja pegawai agen asuransi sebesar $42,7 \%$. Kondisi ini menunjukkan bahwa semakin tinggi budaya organisasi yang diterapkan dan kepuasan kerja yang dirasakan oleh pegawai agen asuransi maka semakin tinggi kinerja pegawai agen asuransi. Namun berdasarkan model persamaan regresi yang dihasilkan diprediksikan bahwa dibutuhkan tambahan variabel independen lainnya yang cukup besar (banyak) untuk dapat menghasilkan nilai kinerja pegawai agen asuransi yang positif. Hal ini ditunjukkan oleh nilai konstansta negatif yang cukup besar. 
5. Sehingga walaupun seandainya nilai budaya organisasi dan kepuasan kerja diberikan nilai terbesar, dalam penelitian ini yaitu nilai 5 , kinerja yang dihasilkan masih menunjukkan nilai yang negatif. Oleh karena itu diprediksikan bahwa tidak cukup hanya dari sisi budaya organisasi dan kepuasan kerja saja untuk menjadikan kinerja pegawai agen asuransi positif tetapi masih dibutuhkan faktor lainnya yang mempengaruhi kinerja pegawai agen asuransi yang dapat dikembangkan dalam penelitian selanjutnya.

6. Berdasarkan analisis matrik korelasi antar dimensi pada variabel budaya organisasi dan kinerja pegawai agen asuransi, pengaruh terkuat pada dimensi integritas dari variabel budaya organisasi terhadap dimensi kemandirian dari variabel kinerja pegawai agen asuransi. Sedangkan analisis matrik korelasi antar dimensi pada variabel kepuasan kerja dan kinerja pegawai agen asuransi, pengaruh terkuat pada dimensi rekan kerja dari variabel kepuasan kerja terhadap dimensi efektifitas dari variabel kinerja pegawai agen asuransi.

\section{Saran}

Berdasarkan hasil penelitian maka rekomendasi yang dapat diberikan dalam penelitian ini adalah :

1. Bagi Manajemen Bumiputera Kantor Wilayah Syariah Jakarta.

a. Hendaknya manajemen tetap menjaga kinerja pegawai agen asuransi yang sudah cukup baik dan terus melakukan pengukuran kinerja secara berkala. Hendaknya manajemen terus membangun budaya organisasi dan meningkatkan kepuasan kerja pegawainya.

b. Dalam membangun budaya organisasi, aspek dimensi integritas harus menjadi perhatian utama karena dimensi tersebut memiliki pengaruh yang sangat signifikan terhadap kinerja pegawai agen asuransi. Hal yang dapat dilakukan manejemen adalah dengan mengadakan secara rutin kegiatan pendalaman keagamaan seperti bagi pegawai muslim yaitu : ceramah dan sholat dhuha bersama, sholat wajib berjamaah dan tepat waktu, bersedekah jamaah kepada panti asuhan ataupun kepada orang yang membutuhkan, dan lain sebagainya. Untuk pegawai non muslim juga dilakukan sesuai dengan ibadahnya. Selain itu pula manajemen dapat melakukan sosialisasi dan pemahaman mengenai peraturan perusahaan. Memberikan apresiasi yang lebih baik kepada pegawai yang berintegritas tinggi dan dapat menjaga amanah perusahaan dengan baik.

c. Sedangkan dari hasil penelitian kepuasan kerja, dimensi rekan kerja memiliki pengaruh yang paling signifikan terhadap kinerja pegawai agen asuransi. Hal ini dapat menggambarkan bahwa pekerjaan pegawai agen asuransi merupakan pekerjaan sebuah tim dan bukan pekerjaan per individu. Sehingga manajemen dapat membangun kepuasan terhadap rekan kerja menjadi hal yang diprioritaskan. Kebersamaan antar pegawai akan menciptakan suasana kerja yang kondusif bagi pegawai untuk akhirnya menghasilkan kinerja yang maksimal. Hal yang dapat dilakukan manajemen adalah secara berkala mengadakan kegiatan kebersamaan antara pegawai seperti berlibur bersama, pelatihan bersama, dan permainan simulasi kerjasama menghadapi kasus asuransi, dan lain sebagainya yang mendorong terciptanya keakraban dan kepuasan terhadap rekan kerja. Selain itu pula segera meminimalkan konflik yang terjadi sesama rekan kerja dengan memberikan keputusan yang tepat dan dapat diterima oleh semua pihak.

2. Bagi Pegawai Agen Asuransi

a. Pegawai agen asuransi jiwa harus dapat meningkatkan kinerja mereka dengan baik terutama dalam produktifitas polis dan produktifitas premi karena menjadi indikator penilaian utama dari kinerja pegawai agen asuransi. Selain itu pula harus dapat meningkatkan integritasnya yang akan mendukung peningkatan kinerjanya.

b. Setiap pegawai agen asuransi jiwa harus dapat meningkatkan pengetahuan dan mengupdate informasi terbaru yang berguna bagi kegiatan keagenan mereka. Terutama yang berhubungan dengan kepercayaan dan kepuasan pelayanan terhadap pemegang polis.

c. Selalu aktif dan proaktif dalam kegiatan kebersamaan yang dilaksanakan oleh manajemen dalam rangka meningkatkan hubungan emosional antara pegawai agen asuransi dan perusahaan.

3. Bagi Peneliti Selanjutnya

a. Dari persamaan regresi yang dihasilkan dan hasil uji R Square menunjukkan masih ada variabel-variabel lain yang perlu diperhatikan dalam penelitian ini. Penelitian lebih lanjut, hendaknya menambah variabel lain yang dapat mempengaruhi kinerja pegawai agen asuransi yang tidak diukur dalam penelitian ini seperti variabel motivasi, pelatihan, kompensasi, kepemimpinan, dan lain sebagainya.

b. Sebaiknya penelitian terhadap pengukuran kinerja pegawai agen asuransi dilakukan secara berkala sehingga data yang didapat adalah data time-series. Selain itu pula dapat dijadikan indikator keberhasilan peningkatan kinerja bagi perusahaan, 
para pegawai agen asuransi, dan bagi peneliti selanjutnya.

\section{DAFTAR PUSTAKA}

As'ad. 2003. Kepemimpinan Efektif Dalam Perusahaan. Edisi.2. Yogyakarta : Liberty.

Davis, Keith, dan Newstrom, W., John. 1989. Human Behavior At Work: Organizational Behavior. New York: Mc Graw Hill International.

Gomes, Faustino Cardoso. Manajemen Sumber Daya Manusia. 1995 Yogyakarta : Andi Offset

Hasibuan Malayu S.P. 1999. Organisasi \& Motivasi. Dasar Peningkatan. Produktivitas. Jakarta: BumiAksara

Martoyo, Susilo. 2000. Manajemen Sumber Daya Manusia. Yogyakarta: BPFE.

Marwansyah. 2010. Manajemen Sumber Daya Manusia Edisi Kedua. Bandung: Alfabeta.

Moeljono, Djokosantoso. (2005). Budaya

Organisasi dalam Tantangan. Jakarta: PT. Elex Media Komputindo.

Robbins, Stephen P. 2001. Perilaku Organisasi: Konsep, Kontroversi, Aplikasi, Jilid. 1, Edisi 8, Jakarta : Prenhallindo

Rivai, Veithzal dan Sagala, Ella Jauvani. 2010. Manajemen Sumber Daya Manusia untuk Perusahaan dari Teori ke Praktik. Jakarta: PT Raja Grafindo.

Schermerhorn. 1996. Management, Tenth Edition New York: John Wiley

Schemerhorn, John.R, James G. Hunt, and Richard N. Osborn. 1991. Managing Organization Behaviour. 4th edition John Wiley and Sons, inc

Stoner, A.F, James, et. al,. 2005. Manajemen. Edisi Bahasa Indonesia. Alih Bahasa: Alexander Sindoro. Jakarta : PT Buana Ilmu Populer.

Sulistiyani. 2003. Meningkatkan Kinerja dan Produktivitas Kerja. Bandung : Mandar Maju 
